Herger Csabáné

DOI: 10.15170/DIKE.2019.03.01.03

habilitált egyetemi docens

PTE ÁJK

\title{
A mediáció a magyar bontójogban 1952 előtt
}

\section{Mediation in Hungarian Divorce Law before 1952}

This study is the second part of the presentation "Protection of Family and Marriage in the Modern Hungarian Private Law" held on the $1^{\text {st }}$ Family Law Workshop of the Deasón Márkus Research Group for Comparative Legal History. In this paper the intention is dealing with a single equipment for the protection of marriage: the conciliation as a bistorical prelude of mediation. The conciliation will be presented as an institution of marriage law of the denominations before 1895 and as an institution of the secular divorce law after 1895 (ordered by the Act XXXI of 1894 on Marriage and the Act I of 1911 on Civil Procedure). Its goal, method and effectivity will be analysed in the mirror of mediation in the Hungarian divorce law in force.

Keywords: mediation, conciliation, divorce law

\section{A témaválasztás indokolása}

Az alternatív konfliktuskezelés módjai, többek között a bírósági közvetítői eljárás népszerú és nagy figyelmet kiváltó téma a jogi szakirodalomban. Mivel ennek történelmi előzményeként a családjogi művek szerzői rendszerint a békéltetés intézményére hivatkoznak, ${ }^{1}$ nem felesleges megvizsgálni, hogy milyen formában, mikor és milyen céllal alkalmaztak békéltetést a hazai jogfejlődésben, továbbá melyek azok a tanulságok, melyek akár korunk mediátorai számára is segítséget nyújthatnak munkájukhoz.

A vizsgálat kiindulópontjaként rögzíthető állítások a következők. Egyrészt a békéltetés sosem a bontást helyettesítette, hanem a kánoni eljárásjogban a favor matrimonii elvcsoporton belül (amely a kötelék védelmét szolgáló eszközök összességét jelentette²) az ágytól és asztaltól történő ideiglenes vagy örökös elválasztás (divortium particulare, separatio a thoro et mensa) iránti perekben alkalmazták. ${ }^{3}$ A kánonjog, majd a 16. század óta a protestáns felekezeti jogok egyaránt egy közérdekből különösen fontos intézmény, a házasság fennállását védték ilyen módon, ${ }^{4}$ ezért volt természetes a továbbélése a szekularizált házassági jogban is. Másrészt fontos azt is rögzíteni, hogy a békéltetést a felekezeti jogokban egyoldalú bontás esetén használták, hiszen a protestáns felekezeti jogok többnyire kifejezetten elzárkóztak a kölcsönös megegyezésen alapuló bontástól, azaz csak szűk körben, kizárólag vétkességi elv alapján tették azt lehetôvé. Ennek a házassági kötelék védelmét szolgáló eljárásjogi eszköznek a hatékonysága ugyan a felekezeti és a bírói békéltetés

\footnotetext{
1 Lásd NAGY Márta: A házasság megszűnése 34.

${ }^{2}$ MÓRA, Házassági kereseti jog 133.

${ }^{3}$ MÓRA, Házassági kereseti jog 129-131.

${ }^{4}$ SCHERMANN, A házasságjog kézikönyve 240.
} 
esetén is korlátozott volt, hatályos jogunk bírósági közvetítői eljárásának megértéséhez hozzájárulhat a békéltetés intézményének körültekintő bemutatása, amelyre ebben a tanulmányban korábbi kutatásaim ${ }^{5}$ alapján teszek kísérletet.

\section{A békéltetés}

\subsection{A mediáció vagy békéltetés?}

A közvetítői eljárást (mediáció) a posztmodern európai családjogban ${ }^{6}$ a családi jogviták alternatív vitarendezési módjai között tartják számon a határon átnyúló jogvitákban és a nemzeti jogokban is. A mediáció (mediare = középen állni, egyeztetni, közvetíteni, békéltetni) ,obyan sajátos permegeló₹o", konfliktuskezeloló, vitarendezó eljárás, melynek célja a vitában érdekelt felek köllcööös megegyezése alapján a vitában nem érintett, harmadik személy bevonása mellett a felek közötti vita rendezésének megoldását tartalmazó írásbeli megállapodás létrehozása”7 A mediáció egy altípusának tekinthető bírósági közvetítôi eljárásnak az elsődleges célja - a lelkészi vagy bírói békéltetéssel szemben - az, hogy a házastársak bontási szándéka esetén a vitás kérdések megegyezéses rendezésében segítsen, bár természetesen az sem kizárt, hogy a házastársak kapcsolatának helyrehozatalához is hozzájárul. A bírósági közvetítés lehetőségével a házastársak a 2013. évi V. tv. (Ptk.) Családjogi Könyve szerint (4:22. §) a bontóper megindítása előtt illetve alatt saját elhatározásukból vagy a bíróság kezdeményezésére élhetnek, kapcsolatuk valamint a házasság felbontásával összefüggő vitás kérdések rendezése érdekében. A szülői felügyelet gyakorlásának rendezésével valamint a szülő és a gyermek közötti kapcsolattartással összefüggő kérdésekben a bíróság vagy a gyámhatóság el is rendelheti a közvetítés igénybevételét. Ebben az esetben a felek a bírói vagy a hatósági rendelkezésnek megfelelően ugyan kötelesek megjelenni a közvetítő előtt, aki azonban csupán az alternatív vitarendezés lehetőségéről tájékoztatja őket. A bírói közvetítés nem a házastársi konfliktus kezelésére, a békéltetésre irányul, hanem arra, hogy a mediátor semleges kívülállóként esélyt teremtsen a bontóper járulékos kérdéseiben történő megegyezésre, melyet a bíróság perbeli egyezségbe foglal ahelyett, hogy maga döntene ezekben, nyilvánvalóan legalább az egyik fél akaratával szemben. A legfontosabb különbség azonban a lelkészi illetve bírói békéltetés és a bírósági közvetítői eljárás között abban lelhető fel, hogy hatályos jogunk szerint a bíróság csak ösztönzi a feleket a közvetítői eljárás igénybe vételére, míg a békéltetés kötelezően alkalmazandó eljárásjogi eszköz volt.

\subsection{A békéltetés típusai a házassági eljárásjogban 1952 előtt}

A békéltetés intézménye a kánonjogból a világi jogba az állami bíróságok házassági ügyekben követendő eljárását szabályozó rendeletek közvetítésével került át. A magyarországi protestánsok esetében ilyen volt II. József 1786. március 6-án kiadott rendelete, a magyarországi izraeliták köteléki pereit tekintve pedig az 1863. november 2-án kelt 15.940. sz. udvari kancelláriai rendelet. A polgári házasságról szóló 1894. évi XXXI. tc. (Ht.) hatályba lépése (1895. október 1.) előtt hazánkban házassági vagyonjogi perekben állami bíróságok jártak el, míg házassági köteléki perekben egy

\footnotetext{
${ }^{5}$ HerGER, A nővételtől az állami anyakönyvvezetőig 183-185. és HERGER, A házasság és a család védelme 3-15.

${ }^{6}$ Lásd 2008/52/EK irányelvet.

${ }^{7}$ GYENGÉNÉ NAGY, A mediáció az igazságszolgáltatásban 6.
} 
nehezen áttekinthető rendszer érvényesült: a római és görög katolikusok, a görög keltiek, az unitáriusok valamint az erdélyi protestánsok és izraeliták házassági ügyei egyházi törvényszék előtt felekezeti jog szerint nyertek elbírálást mind anyagi, mind eljárási szempontból, de a Királyhágón innen élő protestánsok és izraeliták házassági ügyeiben itélkező állami bíróságok ítéltek. ${ }^{8}$ Ezek gyakorlata elsősorban az 1840. évi XV. tc. II. részében szabályozott és az Ideiglenes Törvénykezési Szabályok (1861) által módosított rendes szóbeli eljáráson alapult a házassági ügyek természetéhez igazodó eltérésekkel, a bizonyítási illetve a fellebbviteli eljárás vonatkozásában pedig az 1868. évi LIV. törvénycikken, majd a későbbiekben az 1881. évi LIX. törvénycikken és az 1893. évi XVIII. törvénycikken, ugyancsak a házassági ügyek természetéhez igazodó eltérésekkel. A Budapesti Királyi Ítélőtábla 1882-ben mindezeket a szabályokat összefoglalta, és 1890-ben Házassági szabályzat a polgári bíróságok elé tartozó házassági válóperekben cím alatt (Hsz.) nyomtatásban is megjelentette. Hivatalos jelleggel ez az összefoglalás nem rendelkezett.

A lelkészi békéltetés tehát a polgári házasságról szóló 1894. évi XXXI. tc. (Ht.) hatályba lépésével (1895. október 1.) polgári joghatályát a gyakorlatban elvesztette, a felek magánügye lett, hogy igénybe vették-e ezt a lehetőséget. Ezért a házastársak vallását igazoló okiratot és a lelkészi békéltetésrôl szóló bizonyítványt ezután a keresetlevélhez csatolni nem kellett. ${ }^{9}$ A bírói békéltetés azonban továbbra is megmaradt. A joggyakorlat - az előzményekkel megegyező módon - ezután sem kívánta meg a békéltetést semmisségi perekben, mivel azt teljesen értelmetlennek találta, megtámadási, ágytól és asztaltól történő elválasztásra irányuló és bontó perekben azonban igen, sôt a Ht. 77. \ b, pontjára alapított kereset esetén is, azaz ha az alperes fél ismeretlen helyen tartózkodott. ${ }^{10}$ Mivel eljárásjogi kódex a Ht. hatályba lépésével egyidőben nem készült, és a házassági köteléki perekben alkalmazott eljárást maga a Ht. csak érintőlegesen szabályozta, alapvetően (azaz a Ht. által felállított keretek között) továbbra is az eddigi eljárási rend érvényesült. A jogalkalmazók munkáját Márkus Dęsố, pestvidéki királyi törvényszéki bíró, ${ }^{11}$ Szteblo Kornél, a polgári házasság ügyéért és az egyházi modernizációs törvényekért elkötelezetten fellépő evangélikus vallású ügyvéd, valamint Tóth Gáspár, a jogalkalmazás gyakorlati nehézségeit ugyancsak jól ismerő ügyvéd ${ }^{12}$ eljárásjogi összegzése segítette. A Ht. hatályba lépése után a curiai gyakorlat ezt az eljárási rendet finomította.

Első polgári eljárásjogi kódexünk (1911. évi I. tc., Pp.) a békéltetés intézményét tekintve túlnyomó részben azon az úton haladt, amit a 19. századi előzmények kijelöltek a számára. A békéltetés célja a házassági kötelék fenntartását illetve a bontások lehetőség szerinti legszűkebb körre való szűkítését célozta úgy a Ht. értelmében, ${ }^{13}$ mint a Pp. miniszteri indokolása szerint. ${ }^{14}$ Míg

\footnotetext{
${ }^{8}$ A vegyes házassági válópereket szabályozó 1868. évi XLVIII. tc. szerint először az alperes illetékes bírósága járt el, majd miután az alperes felett kimondott ítélet jogerőre emelkedett, a per hivatalból átkerült a felperes illetékes bíróságához, hogy felette is ítéletet hozzon. Magyarországi protestáns illetve izraelita fél esetében - értelemszerūen ugyancsak királyi bíróságok jártak el, ha a per tárgya vegyes házasság felbontása volt. A törvénycikk kritikai elemzését lásd HERGER, A nôvételtôl az állami anyakönyvvezetőig 150-151.

${ }^{9}$ SZTEHLO, Eljárás a házassági perekben 29.

10 SZTEHLO, Eljárás a házassági perekben 42.

${ }^{11}$ MÁRKUS, Házassági eljárás I. 105., II. 114-115., III. 122-123., IV. 137-138. V. 149-150. valamint A házassági jog és az anyakönyvi törvény kézikönyve.

12 TÓTH, Eljárás házassági perekben I-II-III.

${ }^{13}$ Lásd LADÁNYI, Bíráskodás házassági perekben 401.

14 A törvényjavaslat miniszteri indokolását idézi FABINYI, A polgári perrendtartás 104.
} 
azonban 1911 előtt a bíróság előtti békéltetésre akkor került sor, ha a kereset alkalmas volt az idézés kibocsátására (azaz a kereset beadását követő békéltetésről volt szó), a kódex a békéltetés kettő plusz egy változatát ismerte; az első kettőben kifejezetten a bontó- és válóperek esetében, az utóbbiban pedig a békéltetés lehetőségét a megtámadási perekre is kiterjesztve. Előzetes békéltetést (Pp. 645-647. \S) a peres fél kérhetett, a bontó- és válókereset benyújtása előtt, a perre illetékes törvényszéknél. Kivételt képezett, ha a keresetet elmebeteg házastárs nevében annak törvényes képviselője indította, a perbeli ellenfél volt elmebeteg vagy tartózkodási helye ismeretlen volt (645. $\int$ 2. bek.). A Pp. a békéltetés második formájaként a keresetlevél beadását követő előzetes békéltetést intézményesítette két esetre nézve: ha az előző formával a felek nem éltek, vagy a sikertelen kísérlet óta több mint 30 nap eltelt már (Pp. 654. \$1. bek.). A békéltetés harmadik formája a bontó- vagy válóper illetve (az elősző két formától eltérően) megtámadási per során, annak bármely szakaszában megkísérelt békéltetés (Pp. 668. \$) volt, amelyet kiküldött vagy megkeresett bíró is végezhetett. A békéltetésre ekkor ugyancsak hivatalból került sor, a bíró belátásától függően, nem pedig kötelező jelleggel.

Az 1895. október 1-jétől érvényesülő szabályok és a Pp-ben rögzítést nyert házassági köteléki perekben követett eljárás közötti jelentős átfedést két okkal magyarázhatjuk. Egyrészt a Hsz-ből táplálkozó, Márkus, Sztehlo és Tóth szisztematikus összefoglalásával útjára indított bírói joggyakorlat zökkenőmentes ítélkezési rendet biztosított, amit finomítani kellett csak. Tehát kipróbált és a magyar viszonyokhoz igazodó rendrôl volt szó, amely indokoltan képezhette az eljárásjogi kódex alapját. Másrészt a családvédelem és az állami kényszer tilalmának célzata a Pp. megalkotóinak szeme előtt is ott volt, mégpedig együttesen. Szivák Imre szavaival élve „Két fontos elv áll itt egymással szemben: a felek autonómiájának és azállami szempontnak az elve, mely szerint ügyelni kell a házasság lehetó fenntartására". 15

\subsection{Békéltetés a felekezeti jogokban}

A katolikus szentszékek eljárásában házassági ügyek egyrészt bontó akadály fennforgása miatt házasság érvénytelenné nyilvánítása iránti perek (processus vinculares), másrészt ágytól és asztaltól történő ideiglenes vagy örökös elválasztásra irányuló perek (processus separationis a thoro et mensa), harmadszor pedig a szentszéki ügyész által a házasságzavarók, az önkéntes elválásban élő házastársak vagy az ágyasságban élők ellenében indított perek lehettek. ${ }^{16}$

A házasság érvénye elleni perben a keresetet írásban vagy szóban benyújtó fél köteles volt a bíróság előtt személyesen megjelenni, hogy arra nézve bővebb felvilágosítást nyújtson. Ha a kereset gyenge alapokon állt, a bíróság a felet rögtön felszólította annak visszavonására. Ha a házassági akadály valóban fennállt, de dispensatio által megszüntethető volt, a bíróság a feleket megidézve azokat dispensatio kérvényezésére utasította, vagy ha ez nem volt lehetséges, a házasság érvénye elleni pert folyamatba tette. ${ }^{17} \mathrm{~A} z$ utóbbi esetben a felek az első tárgyalásra kötelesek voltak

\footnotetext{
${ }^{15}$ FABINYI, A polgári perrendtartás 89-90.

${ }^{16}$ KAZALY, A katholikus egyházjogtan kézikönyve 669.

17 KAZALY, A katholikus egyházjogtan kézikönyve 670. Lásd a dispensatio kérésére való utasítást a Codex Iuris Canonici 1965. kánonjában is.
} 
- szükség esetén kényszerítő eszközök alkalmazásával - személyesen megjelenni kihallgatásra, míg a későbbiekben a képviselet is elegendő volt. Itt békéltetés nem történt.

Ágytól és asztaltól történő elválasztásra irányuló pernél azonban a keresetet benyújtó köteles volt szándékát előzetesen a plébánosával tudatni. A plébános „mindkét felet maga elé idéżte, $s$ emlékezzetükbe hozza az Úr oltára elött tett kölcsönös hüségi igéretüket, ökeet kibékiteni, s az elválási sqándékról kifejtve annak hátrányait, lebeszélni törekszik.”. ${ }^{18} \mathrm{Ha}$ ismételt kibékítési kísérlete sem volt eredményes, erről a szentszéket értesítette, ami után a per kezdetét vette. ${ }^{19}$

Ha a közjogi jellegú bontó akadály miatt érvénytelen házasságot senki sem támadta meg, a szentszéki ügyész hivatalból indított köteléki pert, mint ahogy a szentszéki gyakorlat szerint ő tette ezt házasságháborítók, az önkéntes elválásban élők és az ágyastartók ellen is. Az egyházi álláspont az volt, hogy az önkéntes elválásban élők esetében a törvény szelleméből következően megmaradt a szentszéki hatáskör az 1868. évi LIV. tc. hatályba léptét követően is ${ }^{20}$ hiszen a válóperekkel szoros kapcsolatban álló ügycsoportról volt szó. Bár itt békéltetésre nem került sor, az ügytípus önmagában is a kötelék fenntartására irányult.

A békéltetés intézményét ismerte a magyarországi protestánsokra vonatkozóan II. József 1876. március 6-án kiadott rendelete, a magyarországi izraeliták köteléki pereit tekintve pedig az 1863. november 2-án kelt 15.940. sz. udvari kancelláriai rendelet is. Az (állami jogi normában szabályozott) felekezeti köteléki jog alapján eljáró állami törvényszékek előtt a bontóper megindítása tehát a lelkészi illetve rabbinátusi békéltetéstől függött.

T. Júlianna és S. János 1869. január 20-án Harasztiban az evangelica reformata vallás szertartás szerint kötött házasságot. Felperes nő bontó keresetét elsősorban arra alapította, hogy férje házasságot tört, majd háromévi együttélés után elhagyta. Másodsorban - biztos, ami biztos - a protestáns bontóperekben megszokott okot is megjelölte: köztük a történtek hatására engesztelhetetlen gyülölet áll fenn. Házasságukból gyermek nem született, vagyoni igényt férjével szemben T. Júlianna nem támasztott, azonban a bontáson túl keresetében azt is kérte, hogy a bíróság engedélyezze mindkettőjük számára az újraházasodást. Kérelméhez csatolta a háromszori sikertelen lelkészi békéltetést rögzítő bizonyítványt is. ${ }^{21}$

A bontási szándékot, legyen szó egyoldalú akaraton alapuló bontásról, közös megegyezésről (izraeliták esetén) ${ }^{22}$ vagy engesztelhetetlen gyűlöletről (protestánsok esetén), a felek indokaikkal együtt először lelkészüknek illetve rabbijuknak voltak kötelesek bejelenteni, aki „,barátságos egyęttetés során” köteles volt őket „összekelésök alkalmával kölcsönösen tett ünnepélyes igéretökke emlékęztetni, s az elválás káros következményeit hathatósan szivökre kötni”. ${ }^{23} \mathrm{Ha}$ a békéltetés sikertelen volt, kétszer megismételték. A harmadik békéltetés sikertelenségét a lelkész illetve rabbi a felek által is aláirt bizonyítványban rögzítette, amelyet a szükséges bizonyítékokkal együtt a rendes bírósághoz

\footnotetext{
${ }^{18}$ KAZALY, A katholikus egyházjogtan kézikönyve 673.

${ }^{19}$ A Codex Juris Canonini 1926. kánonja fenntartotta a békéltetést, azonban úgy, hogy azt a bíró kötelezettségévé tette, de helyette rendszerint más pap, legtöbbször az illetékes plébános végezte el, és a keresetlevél beadására is a plébánoson keresztül került sor. Lásd SCHERMANN, A házasságjog kézikönyve 224.

${ }^{20}$ KAZALY, A katholikus egyházjogtan kézikönyve 675.

${ }^{21}$ Magyar Nemzeti Levéltár Baranya Megyei Levéltára (MNL BML) VII/2b II/1872/188 2954p/1873. sz.

22 Izraelitáknál az engesztelhetetlen gyúlölet az 1863. november 2-i udvari kancelláriai rendelet szerint bontó okul nem szolgálhatott. Ilyen esetben a feleket a Curia 2152/1885. sz. határozata szerint kölcsönös beleegyezés alapján lehetett egymástól elválasztani. Idézi KASSAY, A zsidó házasságokra vonatkozó jogelvek és szabályok 43.

${ }^{23}$ BEÖTHY, Az evangel. házasságügyi uj törvények 43.
} 
nyújtottak be. ${ }^{24} \mathrm{~A}$ per megindítását követő bírói békéltetésen a felek indokait részletesen jegyzőkönyvezni kellett. Az eljárásra a szóbeli tárgyalás szabályai voltak irányadók olyan eltérésekkel, amelyeket a hivatalból teljesítendő vizsgálat fogalma és célja megkívánt. ${ }^{25} \mathrm{~A}$ kitűzött határnapra a panaszlott fél jelenléte kényszerítő eszközzel is biztosítható volt. A személyesen és együttesen megjelent felek ${ }^{26}$ közül a bíróság először a panaszlót hallgatta ki. A bíró kötelessége arra terjedt ki, hogy a „házastársak perlekedéseit barátságos egyeaség által kiegyenlitse”, ami elsősorban a kereset visszavonására, másodsorban egyoldalú válási szándék esetén a másik fél beleegyezésének a megnyerésére irányult. ${ }^{27}$

T. Júlianna és $S$. János bontó perében azonban nem csak a háromszoros lelkészi, hanem a per megindítását követő egyszeri bírói békéltetés ${ }^{28}$ sem vezetett eredményre. A házasságtörés tényét azonban a felperesi tanúk a bíróság előtt kétséget kizáróan nem igazolták, ezért a fent hivatkozott ítéletben a bíróság 1873. június 20-án felperest keresetétől elmozdította. Döntését igen röviden, az előző egy mondattal indokolta csak. Az elsőfokú ítélet ellen a házasságvédő szokásos fellebbezésén túl T. Júlianna is fellebbezéssel élt. A pesti királyi ítélőtábla ez év szeptember 15-én a törvényszéki ítéletet megváltoztatta, és a felek ágytól és asztaltól való különélését rendelte el két hónapra, a kibékülés céljával. Rendelkezett arról is, hogy ha ezen idő alatt ki nem békülnének, a bírói békéltetést meg kell ismételni. Döntését azzal indokolta, hogy a felperes keresetében az engesztelhetetlen gyülölet bontó okát is megjelölte, ilyen esetben pedig II. József pátense értelmében a fenti eljárást kell követni. ${ }^{29}$ Miután a házasságvédő ismételten fellebbezett, a Curia a másodbíróság ítéletét 1874. január 20-án bármiféle indokolás nélkül helyben hagyta. ${ }^{30} \mathrm{Az}$ ügyben jogerôs ítélet csak a kereset benyújtását követő hetedik évben, 1880. január 19-én született. ${ }^{31}$ A per elhúzódása a házasság védelmét szolgáló eljárásjogi intézmények alkalmazásán túl azzal magyarázható, hogy T. Júlianna a különélésre szabott két hónap után nem rögtön adta be bontó keresetét, hanem - nem tudjuk miért - csak 1879-ben. Ez év október 2-án a pécsi királyi törvényszék ,mivel az engesztelhetetlen gyülölet a különélés alatt nem sqünt meg és az ismételt békéltetés eredményre nem vezetett”, a házasságot felbontotta. ${ }^{32}$ A pesti ítélőtábla a házasságvédő fellebbezését követően, két hónappal később helybenhagyta az elsőbíróság ítéletét, az indokolást azzal kiegészítve, hogy „alperes a bontásba belenyugodott, és kibékülést a lelkészi kisérletek nem eredményez̨tek." ${ }^{33}$ A Curia már hivatkozott helybenhagyó ítélete ezek után már indokolást sem tartalmazott.

\subsection{Békéltetés a Ht. és a Pp. rendszerében}

Mivel a lelkészi békéltetés a Ht. hatályba lépésével polgári joghatályát elvesztette, a felek magánügye lett, hogy igénybe vették-e ezt a lehetôséget. A bírói békéltetést azonban a Ht. a megtámadási, ${ }^{34}$ az ágytól és asztaltól történő elválasztásra irányuló ${ }^{35}$ valamint a bontó perekben ${ }^{36}$ hagyta meg.

\footnotetext{
${ }^{24}$ KASSAY, A zsidó házasságokra vonatkozó jogelvek és szabályok 44.

25 BЕÖTHY, Az evangel. házasságügyi uj törvények 52.

26 A Curia 2333/1887. sz. határozatát lásd KASSAY, A zsidó házasságokra vonatkozó jogelvek és szabályok 44.

${ }_{27}$ BEÖTHY, Az evangel. házasságügyi uj törvények 53.

28 A háromszori rabbinátusi békéltetést követően, bár az 1863. november 2-i udvari kancelláriai rendelet nem szólt róla, a rögzült gyakorlat szerint tartottak bírói békéltetést is a per során, ahogy ez a protestánsoknál történt. Lásd bővebben KASSAY, A zsidó házasságokra vonatkozó jogelvek és szabályok 62.

${ }^{29}$ MNL BML VII/2b II/1872/188 40013p/1873. sz.

${ }^{30}$ MNL BML VII/2b II/1872/188 166p/1874. sz.

${ }^{31}$ MNL BML VII/2b II/1872/188 14126p/1879. sz.

${ }^{32}$ MNL BML VII/2b II/1872/188 2262p/1879. sz.

33 MNL BML VII/2b II/1872/188 55998p/1879. sz.

${ }^{34}$ Ht. 51-55. 』és 56. 』a.

${ }^{35}$ Ht. 105. \$, 76-80. \$§

${ }^{36}$ Ht. 76-80. $\int S$
} 
Az 1911. évi I. tc. előkészítésekor a házassági eljárás tekintetében az I. bizottságban parázs vita folyt a békéltetés intézményének megtarthatóságáról illetve annak formájáról. Issekutz Győző azon a visszafogott állásponton volt, hogy abszolút bontó okok esetén (lásd Ht. 76-79. \$S) a békéltetés mellőzhető, míg relatív bontó okoknál (80. \a-d.) kötelező jelleggel szükséges szabályozni. Logikusnak tûnő véleménye valóban indokolhatónak tűnik: abszolút bontó ok fennállása esetén a bírónak fel kellett bontani a házasságot, míg relatív bontó oknál a bíró mérlegelt. A kötelék feloldását csak akkor rendelte el, ha a bontó ok igazolást nyert és a házasság olyan mértékben megromlott, hogy fenntartása a nem vétkes félre nézve elviselhetetlenné vált. Az ún. feldúltsági elv eme segítségül hívása - elméletileg - azt jelentette, hogy relatív bontó okra alapított keresetnél a békéltetésnek valóban lehet szerepe. Issekutz azonban nem vonta le a kellő következtetést az 1894 óta eltelt időszak statisztikai mutatóiból. A Pécsi Királyi Törvényszék előtt indított perek fennmaradt iratanyagának vizsgálata - az országos mutatókkal összhangban - azt igazolta, hogy gyakorlati jelentôsége a feldúltsági elvnek nem volt. Ha a bontó ok fennállt, a bíró a feldúltságra nézve beszúrt egy sablonmondatot az itéletbe, és bontott. ${ }^{37}$ Issekutz álláspontja éppen ezért nem állt meg.

Plósz Sándor úgy látta jónak, hogy „a javaslat bizonyos kivételes eseteket nem tekintve nem fakultative, hanem kötelezọen szabja meg” a békéltetést. Mandel Pál hangsúlyozta, hogy a békéltetés többször eredményre vezetett a múltban is, „és még eredményesebb lesz a javaslat helyes berendezése mellett. Minthogy

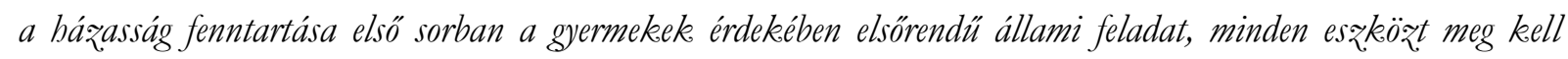
ragadni, (...) ezért a békéltetést mindig meg kell tartani”. Hozzá hasonlóan Simonyi-Semadam Sándor, bár gyermektelen házasságok esetében nem látta szükségszerűnek, közös kiskorú gyermekkel rendelkező feleknél a kötelező békéltetés mellett foglalt állást. ${ }^{38} \mathrm{~A}$ Pp. a békéltetés intézményét tekintve túlnyomó részben azon az úton haladt, amit a 19. századi előzmények kijelöltek a számára. Míg azonban 1911 előtt a bíróság előtti békéltetésre akkor került sor, ha a kereset alkalmas volt az idézés kibocsátására (azaz a kereset beadását követó békéltetésról volt szó), a kódex a békéltetés kettő plusz egy változatát ismerte; az első kettôben kifejezetten a bontó- és válóperek esetében, az utóbbiban pedig a békéltetés lehetőségét a megtámadási perekre is kiterjesztve.

Ht. hatályba lépését követő 24 évében Baranyában a házasságot leggyakrabban azért támadták meg, mert a nő a házasságkötéskor mástól teherben volt, és a férj ugyanekkor ezt nem tudta (Ht. 54. \c.). Mivel az elmebetegség bontó okának törvénybe foglalásától a Ht. megalkotói elzárkóztak, gyakoriságát tekintve másodikként elmebetegség esetén hivatkozott az érvénytelenítést kérő fél arra, hogy házastársa lényeges személyi tulajdonságára nézve megtévesztette, és a megtévesztést a házastárs maga idézte elő vagy tudomása volt arról (Ht. 55. §). Harmadikként említendő, hogy az 54. \ c. pontjára is alapíthatta kérelmét a felperes, mert házastársa már a házasságkötéskor, állandóan képtelen volt a házassági tartozás teljesítésére, és ezt a másik fél nem tudta, és a körülményekből sem következtethetett erre. A házasság érvényességének megállapítására irányuló perek körében a törvényben szereplő egyéb esetek azonban csak kivételesen fordultak elő az említett években. Mindezek fényében nehezen érthető, hogy a Pp. megalkotói a békéltetést a

\footnotetext{
${ }^{37}$ HerGER, A nôvételtől az állami anyakönyvvezetőig 228-232.

38 A véleményeket hosszan idézi FABINYI, A polgári perrendtartás 87-90.
} 
megtámadási perekre is kiterjesztették, hiszen a békülés, bár nem kizárható, ilyen esetekben igen nehezen képzelhető el.

Előzetes békéltetést ${ }^{39}$ a peres fél kérhetett, a bontó- és válókereset benyújtása előtt, a perre illetékes törvényszéknél. Kivételt képezett, ha a keresetet elmebeteg házastárs nevében annak törvényes képviselóje indította, a perbeli ellenfél volt elmebeteg vagy tartózkodási helye ismeretlen volt. ${ }^{40} \mathrm{~A}$ kódex előkészítői úgy ítélték meg, hogy a kereset beadása előtt, külön eljárásban több eredményt ígér a békéltetés, hiszen a kereset beadása feltételezi, hogy a felek közötti viszony véglegesen megromlott. Ennek ellenére kötelezôvé nem tették, hanem a felek belátására bízták, hogy élnek-e ezzel a kötelék fenntartását célzó lehetôséggel. ${ }^{41}$ Ha azonban (kérelem hiányában) az előzetes békéltetés elmaradt, eljárást megsemmisítő hatást - Plósz szavait idézve - ennek nem tulajdonított a Pp.: „, ha már a per folyamatban van, akekor lehetetlen a kereset elötti állapotot visszaállitani, mert a kereset elötti békéltetés biánya ekekor már úgysem pótolható". ${ }^{2}$

A kérelem következtében az elnök vagy az általa megbízott bíró a békéltetésre határnapot tűzött és erre a házasfeleket megidézte, személyes megjelenésre ${ }^{43}$ vonatkozó meghagyással, bár kényszerítő eszközt a megjelenésre vonatkozóan - az előkészítő eljárások általános szabályaitól eltérően - itt a Pp. nem engedett. Ha a személyes megjelenés betegség vagy más fontos ok miatt nem volt lehetséges, a feleket külön is meg lehetett hallgatni, megkeresés útján is. Míg Sz̨tehlo Kornél szerint az 1895 előtti joggyakorlat, ha alperes megjelenése „„žerfeletti nehézségekekel lenne összelötve”, megelégedett alperes bíróilag vagy közjegyzőileg hitelesített nyilatkozatával, ${ }^{44}$ a későbbi években ez a bírói megkeresés lehetőségét jelentette. ${ }^{45}$

A békéltetésen, amelyre a királyi törvényszék előtt, tanácsülésben került sor a Pp. előtti bírói $j^{40 g}{ }^{46}$ és a Pp. szerint is, kizárólag a házasfelek lehettek jelen. A korábbi gyakorlat ezt a szabályt expressis verbis ugyan nem állapította meg, a Pp. törvényjavaslatának miniszteri indokolása szerint a hozzátartozók és a képviselők kizárását a békéltetés természete és rendeltetése indokolta: a hozzátartozók puszta jelenléte is feszélyezheti, bármely mozdulata, gesztusa pedig akadályozhatja a békülési hajlandóság kifejezését. ${ }^{47}$ A Képviselőház Igazságügyi Bizottsága indokoltnak látta a jogi képviselő, a „meghitt ügyvéd” jelenlétét, a Képviselőház plénuma 1910. november 26-án, a 45. ülésen visszatért a miniszteri javaslat álláspontjára.

Felperesnek a békéltetéstől való távolmaradását tekintve némi eltérés volt a Pp. szabályai és a korábbi gyakorlat között. Ha a felperes maradt távol, nem lehetett a békéltetést megtartani, ha pedig a határnap elmulasztását nem igazolta, a pert a bíróság megszüntette. ${ }^{48} \mathrm{~A} \mathrm{Pp}$. szerint ${ }^{49}$

\footnotetext{
${ }^{39}$ Pp. 645-647. SS

${ }^{40}$ Pp. 645. S (2).

${ }^{41}$ A törvényjavaslat miniszteri indokolását idézi FABINYI, A polgári perrendtartás 104.

${ }^{42}$ Az I. bizottság ülésén elhangzott véleményeket idézi FABINYI, A polgári perrendtartás 88.

43 A Pp. hatályba lépte előtti joggyakorlat azonos szabályát lásd SZTEHLO, Eljárás a házassági perekben 44., LADÁNYI, Bíráskodás házassági perekben 402.

${ }^{44}$ SZTEHLO, Eljárás a házassági perekben 44.

${ }^{45}$ LADÁNYI, Bíráskodás házassági perekben 402.

46 Hsz. 19. J

${ }^{47}$ A törvényjavaslat miniszteri indokolását idézi FABINYI, A polgári perrendtartás 106.

${ }^{48}$ LADÁNYI, Bíráskodás házassági perekben 402.; SZTEHLO, Eljárás a házassági perekben 43. Az igazolás rendszerint azt jelentette, hogy a fél képviselője útján jelent meg, aki ügyfele elmaradását indokoltan kimentette és egyben az új határnap tűzését kérte.

49 Pp. 646. \(3)
} 
határnapon nem megjelent kérelmező a békéltető bírónál a határnaptól számított 15 nap alatt új határnap kitűzését kérhette. Ha ezzel a lehetőséggel nem élt, a per szünetelt. ${ }^{50} \mathrm{~A}$ békéltetés kérését ekkor ugyanúgy meg nem történtnek kellett tekinteni, mint ha az ismételt határnapon nem jelent meg a kérelmező. A békéltetésre kitűzött határnap elmulasztása miatt - a korábbi gyakorlattal szemben - igazolásnak nem volt helye; ezt feleslegessé is tette az, hogy a kérelem az említett 15 napon belül ismételhető volt.

$\mathrm{Az}$ alperes igazolatlan távolmaradása a Pp. előtti bírói gyakorlatban egyértelmúen megalapozta a békülés hiányát: mivel alperest az idézésben figyelmeztették az elmaradás következményeire (és ezzel a további megidézést kizárták), a békéltetést megtartották, és megállapították annak sikertelen voltát. Ehhez hasonlóan a Pp., ha a határnapon csak a kérelmező házasfél jelent meg vagy az ellenfél megidézését két ízben is eredmény nélkül kísérelték meg (megjegyzem: nem további megidézésről van szó, hanem sikertelen idézés újra megkísérléséről), a békéltetést sikertelennek tekintették, amelyet a bíró végzésben állapított meg. Felfolyamodásnak e végzés ellen nem volt helye. Mivel a Ht. a bontó vagy váló kereset indítását bizonyos esetekben határidőhöz köti és a békéltetésre e határidôt nyitva tartja, ${ }^{51}$ a Pp. 30 napot adott a végzés kézhezvételét követően a békéltetést kérelmező félnek arra, hogy a váló- vagy bontópert keresetével megindítsa. Fontos, hogy e határnap mulasztása esetén is meg nem történetnek kellett tekinteni a békéltetést, amire végzésében a bíróság figyelmeztette is a kérelmezőt.

A Pp. a békéltetés második formájaként a keresetlevél beadását követő előzetes békéltetést intézményesítette két esetre nézve: ha az előző formával a felek nem éltek, vagy a sikertelen kísérlet óta több mint 30 nap eltelt már. ${ }^{52}$

L. Lajos 1915-ben nyújtott be keresetet a pécsi királyi törvényszékhez felesége, W. Antónia ellen. Az 50 éves kocsmáros a 18 éves kéjnőt 1890-ben Somogyhárságyon vette feleségül, miután a „,şobalány” a kaposvári Szarvas szállodában „,hizelkedésével behálózta” az idősödő özvegy férfit. L. Lajos, bár nejét figyelmeztette, hogy „ne tápláljon ledér gondolatokat” és neki „öreg napjaira támasz. legyen”, rövidesen számos problémával találta szemben magát. A fiatal nő férje fiával összefogva súlyosan bántalmazta a betegeskedő embert, majd elhagyta. Ezek után L. Lajos keresetében a békéltetés és ennek sikertelensége esetén a tárgyalás napjának kitűzését egyszerre kérte. ${ }^{53}$

A bíró belátása szerint kivételesen mellőzhető volt a békéltetés, ha nagy nehézségbe ütközött volna, ́́gy az ellenfél külföldi tartózkodása esetén. ${ }^{54}$ A gyakorlatban ez azt jelentette, hogy csakis ezt az expressis verbis említett esetet fogadták el a mellőzés okaként.

M. Mária 4 hónapi együttélés után hagyta el férjét, és azóta mintegy 34 éven át mindketten ágyasságban éltek. Ahogy a férj ezt keresetében megfogalmazta, „teljes elbidegülés állt be közöttünk, részemröl ez nagyon természetes is, és igazán tragikomikus lenne esetleg békéltetésünk”. Az 1917. január 27-én rögzített jegyzőkönyv ${ }^{55}$ szerint a békéltetést a „körülményektól függetlenül”

50 1893. évi XVIII. tc. 215. 』és 52. 』

${ }^{51}$ Ht. 83. S szerint a 76., 78. 79. és 80. szakaszokban megjelölt bontó ok alapján a keresetet csak attól a naptól számított 6 hónap alatt lehet megindítani, amelyben a vétkes magatartás vagy a 79. \ és a $80 . \int \mathrm{d}$. pontja esetén a büntető itélet a házastárs tudomására jutott. Ez az időintervallum legfeljebb 10 év lehetett. Ezek a szabályok a 105. \szerint ágytól és asztaltól történő elválasztás iránti perben is érvényesültek.

52 Pp. 654.S (1).

${ }^{53}$ MNL BML VII/2b II/1915/1050

54 Pp. 654.S (2).

${ }^{55}$ MNL BML VII/2b II/1916/2922 2922p/17/1916 sz. 
rendelte el a bíróság, melynek során felperes, ahogy ez várható is volt, kijelentette, hogy „nem bajlandó békëulni”, míg alperes úgy nyilatkozott, hogy „,hajlandó uráboz visszatérni”. Mivel ,felperes ezután sem béküilt”, a királyi törvényszék mindkét felet vétkessé nyilvánítva a Ht. 80.S a. pontja alapján bontotta fel a házasságot.

A bíróság a mellőzhetőséget tehát csak akkor állapította meg, ha a házasfél közjegyzői vagy közjegyzőileg hitelesített okiratban hiteles módon igazolta a "tetemes nehérséget”, ${ }^{6}$ és egyben nyilatkozott arról, hogy hajlandó-e kibékülni a házastársával. 1895-től a Pp. hatályba lépéséig eltelt években egyáltalán nem találkoztam Baranyában olyan esettel, amikor a bíróság mellőzte volna a békéltetést, még olyankor sem, ha erre egyáltalán nem volt remény. Ebből következik, hogy a Pp. előtt a békéltetés lényegét tekintve (eredeti formájában vagy az azt pótló nyilatkozat útján) kötelező volt, míg a Pp. ezen utóbbi eszközről nem rendelkezik. A kódex miniszteri indokolása szerint, bár némely esetben a békéltetés mellőzése a bíró belátásától függ, „mivel az előkészitó eljárás és a tárgyalás folyamán a békéltetés bármikor megújitható (lásd a békéltetés harmadik formáját a későbbiekben), nem tulajdonitja annake azt a hatályt, hogy a békeéltetésnek vagy éppen nem, vagy nem az illetékes bíróság elótt történte az eljárást akadályozza, vagy feloldási okul szolgáljon”.57

A békéltetést ugyanazon esetekben egyáltalán nem kellett elrendelni, mint ahogy ezt a keresetlevél beadása előtti békéltetésnél láttuk. Míg azonban ott a felek kérelmére került sor a határnap tűzésére, itt a bíróság hivatalból intézkedett. Egyebeket tekintve azonos szabályokhoz igazodott az eljárás ebben az esetben is. Ebből következik, hogy mulasztott határnap miatt az azt követő 15 napon belül kérelemre újabb határnapot tűzött a bíróság. Ha pedig a kérelmezô azt is elmulasztotta, a keresetet be nem adottnak tekintették. ${ }^{58}$

A békéltetés harmadik formája a bontó- vagy válóper illetve (az elősző két formától eltérően) megtámadási per során, annak bármely szakaszában megkísérelt békéltetés ${ }^{59}$ volt, amelyet kiküldött vagy megkeresett bíró is végezhetett. A békéltetésre ekkor ugyancsak hivatalból került sor, a bíró belátásától függően, nem pedig kötelező jelleggel. A kormányjavaslat miniszteri indokolása szerint a békéltetési kísérlet ismételt megengedése a 231. \-nak felelt meg, és a házassági kötelék fenntartásának előmozdítását célozta. ${ }^{60}$

A Pp. előtti joggyakorlatban kifejezett cél volt a gyors ügymenet. Ennek érdekében a békéltetést és a tárgyalást lehetôség szerint egy napra tűzzék ki, mint ahogy az alábbi, 1905-ben megindított ügyben is történt.

Az 1. ábrán látható tárgyalási jegyzőkönyv szerint a görög-keleti vallású B. Boldizsár és $P$. Sqavéta 1898. február 18-án kötött házasságot. Az asszony második gyermekük, Verona születése után azért hagyta el férjét, mert „kelló ápolásra” otthon nem számíthatott. Amikor egy hét múlva szüleitől férjéhez visszatért, B. Boldizsár elzavarta. Ố maga a bontást ellenezte, férje keresetét követően viszontkeresettel nem élt. Az előzetes békéltetés során kijelentette, hogy ,férjével az együttélést folytatni hajlandó, (...) de férje bázához visszatérni nem fog”. Az ábrán középütt jól olvasható, hogy „a békéltetés

\footnotetext{
${ }^{56}$ A gyakorlat három okot fogadott el: a, betegsége miatt a bíróság előtt meg nem jelenhetik; b, a bíróság székhelyétől távol lakik és szegénységénél fogva az utazással járó költségeket fedezni nem képes; c, külföldön tartózkodik és a békéltetésnek megkeresés útján való foganatosítása tetemes nehézségbe ütközik. Lásd LADÁNYI, Bíráskodás házassági perekben 403 .

57 Idézi FABINYI, A polgári perrendtartás 117.

${ }^{58}$ FABINYI, A polgári perrendtartás 118.

${ }^{59}$ Pp. 668. S

${ }^{60}$ A törvényjavaslat miniszteri indokolását idézi FABINYI, A polgári perrendtartás 131.
} 
eredményre nem vezetvén”, az első tárgyalást ugyan ezen a napon, 1906. május 19-én lefolytatták. A feleket ez év október 31-én egymástól hat hónap időtartamra ágytól és asztaltól elválasztották, ${ }^{61}$ majd mivel a felek a különélés alatt nem békeültek ki, sốt felperes e hat hónap alatt ágyassági kapcsolatot létesitett, házasságukat 1907. augusztus 27-én a Ht. 80. 』a. pontja alapján bontották fel. ${ }^{62} P$. S qavétát azért nyilvánították vétkessé, mert férjét a lakóhelyére nem követte.

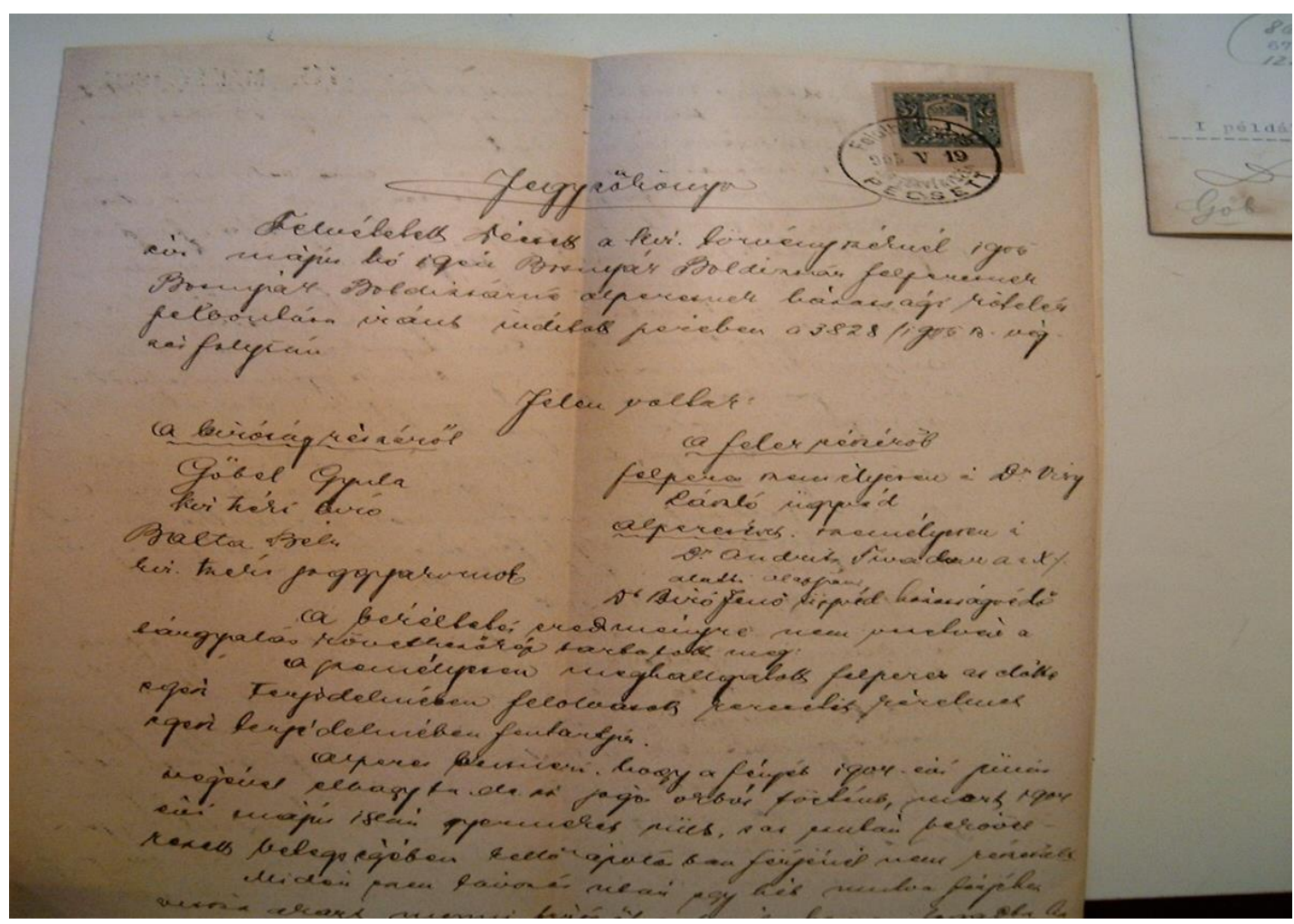

1. ábra: Tárgyalási jegyzőkönyv részlete, 1906. május 19. (MNL BML VII/2b II/1905/110)

A fenti perben követett eljárással szemben a Pp. szerint a békéltetés határnapján, a három említett forma bármelyikéről legyen is szó, az ügyben más nem történhetett. Ha a bíró előtt azonnal nem is járt eredménnyel a békéltetési kísérlet, a jogalkotó nem zárta ki annak lehetőségét, hogy a felek utólag, a dolgot még egyszer átgondolva, megváltoztatják a véleményüket. ${ }^{63}$ Éppen ezért, ha a felek meghallgatása után alapos kilátás volt arra, hogy a békéltetés ismételt megkísérlése eredményre fog vezetni, a bíró újabb határnapot tűzött ki. ${ }^{64}$

\section{3. Összegzés}

Első polgári eljárásjogi kódexünk a házassági perek tekintetében nem új rendet teremtett. A Királyhágón inneni protestánsok és izraeliták házassági ügyeiben (felekezeti anyagi jog alapján) állami törvényszékek jártak el 1894 előtt, és ezek gyakorlatában rögzült a házassági kötelék védelmét

\footnotetext{
${ }^{61}$ MNL BML VII/2b II/1905/110 13461p/1905. sz.

62 MNL BML VII/2b II/1905/110 6721p/1907. sz.

${ }^{63}$ A törvényjavaslat miniszteri indokolását idézi FABINYI, A polgári perrendtartás 117.

${ }^{64}$ Pp. 646. $\int(2)$.
} 
szolgáló eszközök köre illetve azok alkalmazási módja. Amikor 1895 októberében a felekezeti különbségeket figyelmen kívül hagyó, egységes, polgári házassági törvényünk hatályba lépett, a törvényi rögzítést nem nyert eljárás a Ht. elveit és a benne foglalt szabályokat alapul véve túlnyomó részt az addigi rendet követte. A jogpolitikai célzat időközben vajmi keveset változott: a cél továbbra is a házasságok lehetőség szerinti fenntartása volt, figyelembe véve az érintett felek magánautonómiáját. Éppen ezért, amikor a Pp. előkészítése zajlott, a házassági eljárás kapcsán a kötelék védelmét szolgáló eddigi eszközöket számba véve azok hatékonyságát vizsgálták. Csupán a házasságvédő és a kötelező hivatalból történő felülvizsgálat degradálódott a múlt hagyatékává, az egyéb eszközök, így különösen a békéltetés azonban - némi apró finomítással - tovább szolgálhatták azt a célt, hogy a felek kellő megfontoltsággal, csak végső esetben éljenek a bontás lehetőségével.

A Pp. hatályba lépése óta több mint egy évszázad eltelt, és ez alatt hazánkban is jelentősen megváltozott a társadalmi értékszemlélet. A korabeli bírói békéltetés célja és alkalmazása merőben eltért attól, amit hatályos jogunkban a bírósági közvetítés jelent. Az előbbihez visszatérni elképzelhetetlennek (feleslegesnek és idejét múltnak) tűnik. A Ht. hatályba lépése előtti felekezeti házassági jogok lelkészi békéltetése azonban korunk bíróságon kívüli, önkéntes (voluntary) mediátorainak adhat némi muníciót: amennyiben a házastársak vallásos világnézettel rendelkeznek, a felekezeteken belül múködő segítő szolgálatok mediátori funkciót betöltve jelentős mértékben hozzájárulhatnak ahhoz, hogy a házassági kötelék, vagy ahogy Salamon király a Prédikátor könyvében nevezi: a „hármas kötél” ne szakadjon el. ${ }^{65}$

\section{Felhasznált források és irodalom}

1894. évi XXXI. tc. a házassági jogról

1911. évi I. tc. a polgári perrendtartásról

1911. évi I. tv. indokolása a polgári perrendtartásról. https://net.jogtar.hu/ezer-evtorveny?docid=91100001.TVI\&searchUrl=/ezer-ev-torvenyei\%3Fpagenum\%3D46 (2018. 12. 12.)

BEÖTHY Zsigmond: Az evangel. házasságügyi uj törvények gyakorlati magyarázata. Pest 1853

FABINYI Tihamér: A polgári perrendtartás törvénye és joggyakorlata II. Budapest 1931

GYENGÉNÉ NAGY Márta: A mediáció az igazságszolgáltatásban. Családjogi specialitások. PhD-értekezés, Msc, Szeged 2009

HERGER Csabáné: A nővételtől az állami anyakönyvvezetőig. A magyar házassági köteléki jog és az európai modellek. Budapest-Pécs 2006

HERGER Csabáné: A házasság és a család védelme a modern magyar magánjogban. A Márkus Dezső Összehasonlító Jogtörténeti Kutatócsoport tudományos ülésének megnyitójára (Pécs, 2018. december 10.). Díké 2018/2. sz. 3-15.

HUSZÁR Elemér: A katholikus házasságjog rendszere a Codex Juris Canonici szerint. Kalocsa 1927

KASSAY Adolf: A zsidó házasságokra vonatkozó jogelvek és szabályok a megfelelő rendeletekkel és határozatokkal. Budapest 1891

KAZALY Imre: A katholikus egyházjogtan kézikönyve, különös tekintettel Magyarország jogi viszonyaira II. Vác 1877 LADÁNYI Lajos: Bíráskodás házassági perekben. Gyakorlati kézikönyv. Budapest 1910

MÁRKus Dezső (szerk.): Magyar Jogi Lexikon I-VI. Budapest: Pallas Irodalmi és Nyomdai Rt. 1898-1907

MÁRKus Dezső: Házassági eljárás az 1894. évi XXXI. tcz. életbelépte után I. Jogtudományi Közlöny 1895/ 14. sz. 105.

${ }^{65}$ Prédikátor 4:12 
MÁRKUS Dezső: Házassági eljárás az 1894. évi XXXI. tcz. életbelépte után II. Jogtudományi Közlöny 1895/15. sz. 114-115.

MÁRKus Dezső: Házassági eljárás az 1894. évi XXXI. tcz. életbelépte után III. Jogtudományi Közlöny 1895/16. sz. 122-123.

MÁRKUS Dezső: Házassági eljárás az 1894. évi XXXI. tcz. életbelépte után IV. Jogtudományi Közlöny 1895/18. sz. 137-138.

MÁRKus Dezső: Házassági eljárás az 1894. évi XXXI. tcz. életbelépte után V. Jogtudományi Közlöny 1895/19. sz. 149-150.

MÁRKus Dezső: A házassági jog és az anyakönyvi törvény kézikönyve. Budapest: Pallas Irodalmi és Nyomdai Rt. 1895 MÓRA Mihály: Házassági kereseti jog a köteléki perben az egyházjog szerint. Budapest 1941

NAGY Márta: A házasság megszűnése. In: JAKAB András - FEKETE Balázs (szerk.): Internetes Jogtudományi Enciklopédia (Családjog rovat, rovatszerkesztő: HEGEDÜs Andrea) http://ijoten.hu/szocikk/a-hazassag-megszunese (letöltve: 2019. 04. 04.)

SCHERMAnN Egyed: A házasságjog kézikönyve. Pannonhalma 1926

SZTEHLO Kornél: Eljárás a házassági perekben tekintettel az 1894. évi XXXI. törvényczikk életbeléptetésére az eljárást szabályozó törvények és a bírói gyakorlat alapján. Budapest 1895

TÓTH Gáspár: Eljárás házassági perekben I. Jogtudományi Közlöny 1895/37. sz. 290-291.

TÓTH Gáspár: Eljárás házassági perekben II. Jogtudományi Közlöny 1895/38. sz. 299-300. 